\title{
CASE STUDIES OF PRIVATE GOVERNMENT COOPERATION: PROCUREMENT OF LAND DEVELOPMENT PROJECTS TOLL ROAD KRIAN - LEGUNDI - BUNDER - MANYAR
}

\author{
Prasetyo Adi Sungkono ${ }^{1}$, H.Fredy Kurniawan ${ }^{2}$ \\ Narotama University, Surabaya \\ prasetyo.gitara@gmail.com
}

\begin{abstract}
One of the efforts to maintain and enhance the economic growth of a region is supported by the existence of infrastructure development. Infrastructure development in the form of a toll road could increase the potential for the development of the economy of the region through improved the smooth flow of goods and services. Toll road construction project Krian- Legundi - Bunder - Manyar areas is one of national strategic Project (PSN) that are in the shadow of the State Ministry of Public Works and Public Housing (PUPR) with PT. Waskita Bumi Wira as the initiator. The research method used is descriptive qualitative, i.e. by doing observation and interviews with related parties on the project construction of KLBM toll road. The results of this study are: (i) the forms of cooperation carried out in the construction of KLBM toll roads, is Build Operate Transfer (BOT); (ii) the process of acquiring the land in KLBM toll road development projects are the responsibility of PT WBW assisted by PPK Land Procurement and BPN Sidoarjo and Gresik Regency; (iii) Proceedings reversion bailouts land is done through examination by the BPKP and then verified by the LMAN and the value of payments carried out as stated in the agreement.
\end{abstract}

Keywords: BOT, bailouts of land, PT WBW, KLBM toll road.

\section{INTRODUCTION}

One of the efforts to maintain and enhance the economic growth of a region, that is supported by the existence of infrastructure development. Infrastructure development in the form of a toll road could increase the potential for the development of the economy of the region through improved the smooth flow of goods and services. During the last four years, the Government prioritizing sectoral and cross-sectoral reforms to encourage private sector participation in infrastructure development with emphasis on the principle of partnership is fair, open, transparent, competitive, and mutual benefit. The Government's commitment in this partnership of which are visible from a variety of refinements to the policies, regulations, and institutional, as well as the arrangement of Government support and risk management in the project of cooperation between Public Private Partnership (PPP). In some sectors, the PPP also 
Volume 2 Number 2 March 2019

has been implemented even in the provision of infrastructure facilities and services in the territory of a non-commercial with Government incentives as the catalyst.

Toll road construction project Krian - Legundi- Bunder - Manyar areas is one part Presidential Regulation Number 58 Year 2017 about National Strategic Project (PSN) that are in the shadow of the State Ministry of Public Works and Public Housing (PUPR) with PT. Waskita Bumi Wira as the initiator. Krian- Legundi - Bunder - Manyar toll road has 38,29 kilometers long which connects Sidoarjo and Gresik Regency, which starts from the Krian Bypass and ends at Manyar connected to the national road. The toll road passes through the two districts, i.e Sidoarjo and Gresik Regency. The purpose of Krian - Legundi - Bunder - Manyar toll road construction is expected to tackle congestion in the southern Gresik Regency area direct access to Java International Integrated Port and Estate (JIIPE). Krian - Legundi - Bunder - Manyar toll road has signed Toll Road Concession Agreement (TRCA) with 45-year concession period. Krian - Legundi - Bunder - Manyar toll road construction was divided into four (4) sections as follows: section I (Kedamean-Krian areas) with a length of $10.55 \mathrm{~km}$, section II (Kedamean-Boboh) $7.95 \mathrm{~km}$ in length, section III (Boboh-Bunder) $10.50 \mathrm{~km}$ in length, and Section IV ( Bunder-Manyar) $9.29 \mathrm{~km}$ in length.

\section{LITERATURE REVIEW}

The toll road is a public road that is subject to the obligation to pay the wearer to the toll road and is an alternative to cross existing public roads (Nasution, 2010). Providence Highway aims to improve the efficiency of distribution services to support increased economic growth especially in the area of the already high level of development (PP No. 15 of 2005). Since the existence of private involvement in 1987 and the formation of BPJT in 2005, authorities of organizing the highway divided into three parties, namely, the Government, and, BUJT BPJT (Simanjuntak dkk., 2014). The authority conducting the highway include setting, coaching, business development, and supervision of the toll road. Most Government authority in implementing toll roads held by the toll road Regulatory (BPJT) (Presidential Regulation Number 15 Year 2005).

Public Private Partnership (PPP) is a partnership of the Government - private sector involving large investment/capital where private sector finance, build, and manage infrastructure and facilities, while the Government as a partner that handles settings service, in this case remain as owners of assets and control of the implementation of the cooperation. PPP in infrastructure development involving the private sector's participation in any or all stages of the design, construction, financing, and operating the infrastructure phase of the public utilities and services (Raharjanto, 2011). According to The National Council for Public Private Patnership (1999), forms a private Partnership, among others: (i) Build Operate Transfer (BOT); (ii) a Build Own Operate (BOO); (iii) Buy Build Operate (BBO); (iv) Contract Services; (v) Design Build (DB); (vi) Concesion etc. 
Volume 2 Number 2 March 2019

Cooperation between Government and private on the construction of toll roads, namely in terms of acquiring land. Land procurement is the responsibility of the Government and the Fund can come from the The Indonesian Budget, which can be bailed out in advance by the Business Entity. Funds for land acquisition for the construction of Toll Roads are provided by the Government through the agency designated in this case the Public Assets Management Agency of the State (Ministerial Regulation number 18 Year 2016).

\section{RESEARCH METHODOLOGY}

This study aims to find out the applicable regulations regarding the collaboration of the Public Government on procurement, to know the form of cooperation between the Ministry of Public Works and Public Housing with PT. Waskita Bumi Wira in the form of land acquisition, as well as knowing the process of land acquisition and return of land bailouts on the Krian - Legundi - Bunder - Manyar toll road construction project.

\subsection{Data Sources}

The data source in this study is in the form of primary data containing an agreement between the Toll Road Regulatory Agency and the Toll Road Business Entity or PT. Waskita Bumi Wira, the Land Acquisition Process that has been carried out in Sections I and Section III as well as the Procedure for Returning Land Bailings by the State Asset Management Institute to Toll Road Business Entities or PT. Waskita Bumi Wira in 2017 and secondary data is a brief history of the company.

\subsection{Data Collection Techniques}

In collecting data for the process of preparing this research the author uses two methods, namely the method of interviewing and direct observation in the company and looking at the evidence relating to the discussion in accordance with the research.

1) Observation

The researcher looked at the process directly related to the recognition of procedures for land acquisition and the return process of the bailouts land in Krian - Legundi Bunder - Manyar section.

2) Interview

The method of interviewing conducted by researchers is unstructured interviews. Researchers conducted interviews with managers and staff of engineering and land.

3) Documentation

The researcher noted several reports regarding the results of the implementation of compensation in the procurement of land in the Gresik Regency which was affected by land acquisition. Documents that the researchers collected in the form of photographs of compensation processes for land acquisition, land acquisition regulations, list of names of people affected by land acquisition, progress data on the implementation of Land Acquisition on Krian - Legundi Road - Bunder - Manyar toll road. 


\subsection{Research Flowchart}

Research activities during the implementation stage can be seen in the flowchart below:

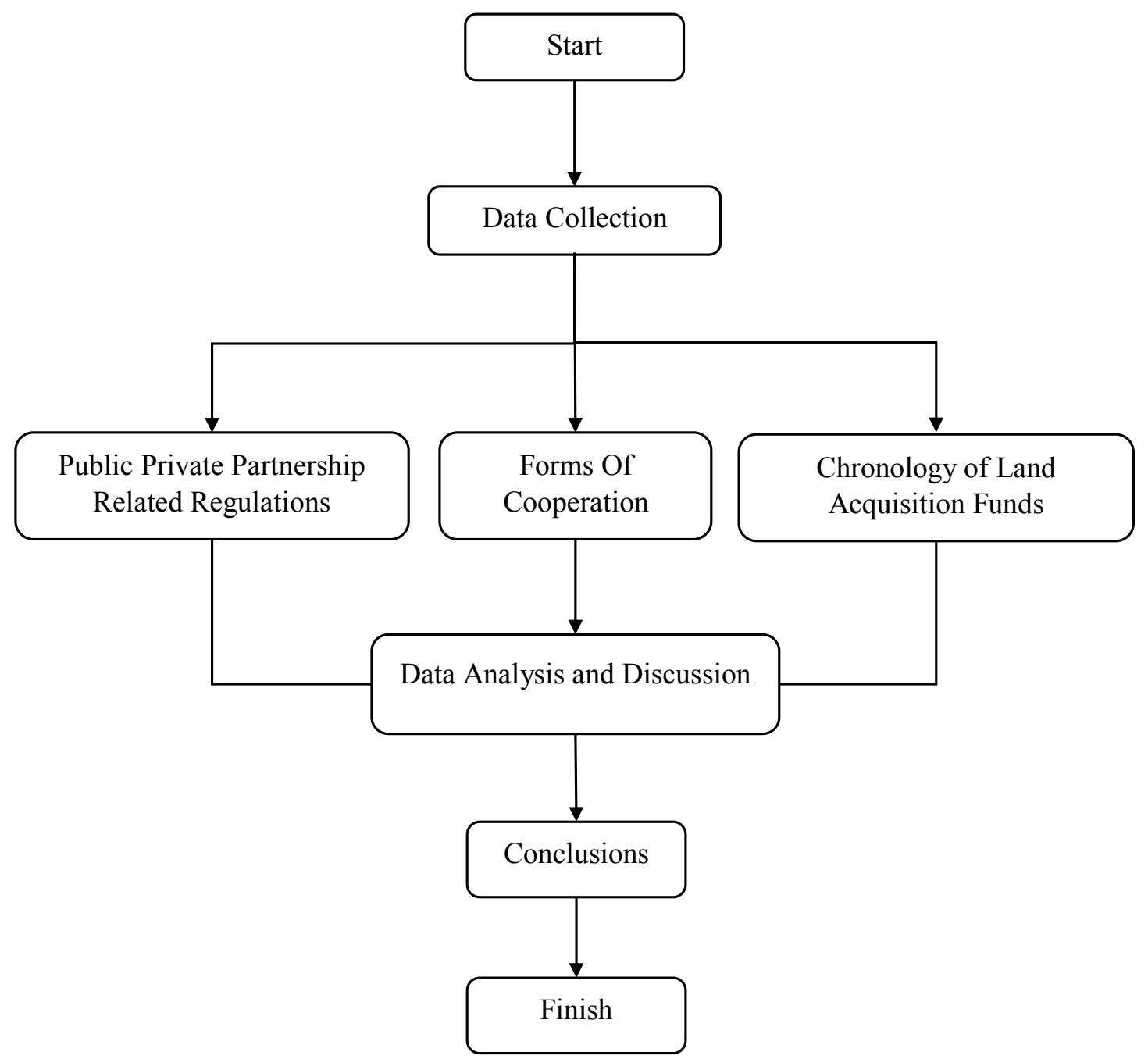


Volume 2 Number 2 March 2019

\section{RESULT AND DISCUSSION}

The most relevant regulation with the cooperation of the government - private sector in the construction of the Krian - Legundi - Bunder - Manyar toll road is Presidential Regulation Number 58 Year 2017 about National Strategic Projects. The Form of Private Government Cooperation that is established between the Ministry of Public Works and Public Housing with PT. Waskita Bumi Wira is a Build Operate Transfer (BOT), this is because both parties, namely the Ministry of PUPR has made a Toll Road Concession Agreement with private companies, namely PT Waskita Bumi Wira. This agreement was made on February 2, 2016 with the Agreement Number: 02 I PKS / M / 2016, 01 / SPPJK / WBW / 2016, about Land Procurement of the Krian Legundi - Bunder Toll Road Section, where the contents of the agreement are about Land Acquisition Funding. The contents of the agreement stated that the cost of land acquisition paid by the initiator would be replaced by the government. In the Minutes of the Agreement the validity period of the Toll Road has been determined, namely for 45 (Forty Five) Years. In addition, the Toll Road Concession Agreement also regulates the return of the Bailouts Land which will be replaced by the Government, namely the State Asset Management Agency.

Land acquisition on the KLBM toll road construction project is the responsibility of PT WBW as the initiator who is obliged to carry out sustainable land acquisition processes, and hand over free land of at least 1 (one) section no later than 1 (one) year to be followed by road concession auction toll road by BPJT. Agreement between PT. WBW with the Ministry of PUPR regarding Toll Road No. Procurement Funding for Toll Road Section 02 / PKS / M / 2016 No. 01 / SPPJK / WBW / 2016 stated that Land Procurement funds for the construction of toll roads section I, II, and III (Krian - Legundi - Bunder) are Rp. 1,112,300,000,000 (one trillion one hundred and twelve billion three hundred million rupiah). Based on the verification carried out by the BPKP, it was stated that:

1) Request for Payment in 2016 (February 2016 - December 2016) Rp. $421,587,611,367$

Eligible Rp. 212,943,982,257, Uneligible Rp. 208,643,629,110, -

2) Request for Payment in 2017 (January 2017 - October 2017) Rp. 133.137.292.332, -

Eligible Rp. 48,767,487,491, -

Uneligible Rp. 84,369,804,841, -

Total Value of BPKP Verification Results: Rp. 554,724,903,699, -. The return of the Land Talangan Fund that has been done by LMAN for the period of January 2017 June 2017 is: Rp. 48,767,487.49, -. 
Volume 2 Number 2 March 2019

\section{CONCLUSIONS AND SUGESTION}

\subsection{Conclusions}

a) Regulations most related to Public Private Partnership on the Construction of Toll Roads Presidential Regulation Number 58 Year 2017 about National Strategic Projects.

b) Form of cooperation between the Ministry of Public Works and Public Housing with PT. Waskita Bumi Wira in the construction of the Krian - Legundi - Bunder Manyar Toll Road (KLBM) is a Build Operate Transfer (BOT).

c) The Land Procurement Process for the KLBM Toll Road construction project is the responsibility of PT WBW as the BUJT which is obliged to carry out sustainable land acquisition processes assisted by the PPK Land Procurement and BPN of Gresik Regency and Sidoarjo. As for the process of returning the land bailout fund by first checking by the BPKP then verified by LMAN. After that, the LMAN leadership paid compensation for land acquisition with a value of as stated in the agreement.

\subsection{Sugestion}

There must be a legal foundation or regulation that applies to the acquisition of Land Bailouts that have been issued by BUJT. Because the delay in disbursing funds will have an impact on development activities.

\section{REFERENCES}

Nasution, S.H. 2010. Analisa Waktu Pelayanan dan Profil Pemakai Jalan Tol di Gerbang Tol Balmera (Studi Kasus:Jalan Tol di Gerbang Tol Belmera). Universitas Sumatera Utara. Medan.

Peraturan Menteri Nomor 18 Tahun 2016 Tentang Penetapan Dan Tata Cara Penggunaan Dana Talangan Badan Usaha Untuk Pengadaan Tanah Jalan Tol.

Peraturan Pemerintah Nomor 15 Tahun 2005 Tentang Jalan Tol.

Raharjanto, Y. 2011. Model Kerjasama Pemerintah - Swasta dalam Peningkatan Kapasitas Jalur Kereta Api Jabodetabek. Universitas Indonesia. Depok.

Simanjuntak, E., Widiastuti, H., Argiono, I., Aramanda, T., Kartika, T.T., Baskoro, L.S., Subkhi, A.N., Lelowati, R., Sumartiny, S., Wicaksono, A.B., Wahyuningsih, M., Aulia, M., Khairunnisa, N. 2014. Peluang Investasi Infrastruktur Bidang Pekerjaan Umum. Pusat Kajian Strategis Kementerian Pekerjaan Umum. Jakarta.

The National Council for Public Private Patnership (NCPPP). 1999. Bentuk-bentuk Kerjasama. http://www.ncpp.org. 